
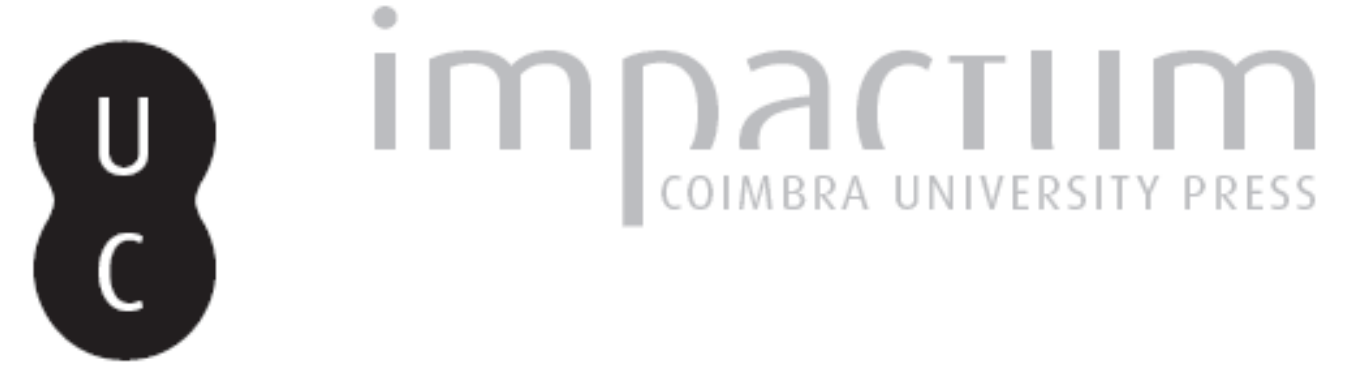

\title{
Plato's theory of punishment in book ix of Laws
}

Autor(es): $\quad$ Cunha, Silvia Regina da Silva Barros da

Publicado por: Imprensa da Universidade de Coimbra; Annablume

URL persistente:

URl:http://hdl.handle.net/10316.2/43661

DOI:

DOI:https://doi.org/10.14195/1984-249X_23_2

Accessed : $\quad$ 26-Apr-2023 01:07:39

A navegação consulta e descarregamento dos títulos inseridos nas Bibliotecas Digitais UC Digitalis, UC Pombalina e UC Impactum, pressupõem a aceitação plena e sem reservas dos Termos e Condições de Uso destas Bibliotecas Digitais, disponíveis em https://digitalis.uc.pt/pt-pt/termos.

Conforme exposto nos referidos Termos e Condições de Uso, o descarregamento de títulos de acesso restrito requer uma licença válida de autorização devendo o utilizador aceder ao(s) documento(s) a partir de um endereço de IP da instituição detentora da supramencionada licença.

Ao utilizador é apenas permitido o descarregamento para uso pessoal, pelo que o emprego do(s) título(s) descarregado(s) para outro fim, designadamente comercial, carece de autorização do respetivo autor ou editor da obra.

Na medida em que todas as obras da UC Digitalis se encontram protegidas pelo Código do Direito de Autor e Direitos Conexos e demais legislação aplicável, toda a cópia, parcial ou total, deste documento, nos casos em que é legalmente admitida, deverá conter ou fazer-se acompanhar por este aviso.

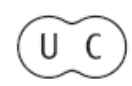




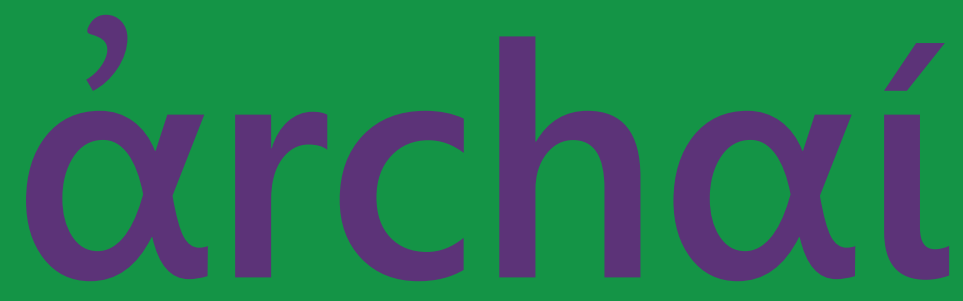

AS ORIGENS DO PENSAMENTO OCIDENTAL

THE ORIGINS OF WESTERN THOUGHT

May - Aug. 2018 
Silvia Regina da Silva Barros da Cunha - Pontifícia Universidade Católica do Rio de Janeiro (Brasil)

silviabcunha@gmail.com - ORCID: 0000-0001-5323-2858

\section{Plato's Theory of PUNish- MENT IN BOOK IX OF LAWS}

BARROS DA CUNHA, S. R. da S. B. (2018). Plato's theory of punishment in book ix of Laws. Archai, n. ${ }^{\circ} 23$, May-Aug., p. 45-75 DOI: https://doi.org/10.14195/1984-249X_23_2

Abstract: The basis of moral responsibility is the central issue of Book IX of Laws, where Plato develops his theory of punishment, conciliating the Socratic thesis that no one is

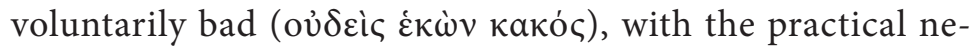
cessity for a gradation of penalties, the latter being derived from the traditional distinction between voluntary and involuntary offences. Distinguishing two independent aspects of crimes - injury ( $\beta \lambda \dot{\alpha} \beta \eta)$ and injustice ( $\dot{\alpha} \delta\left\llcorner\kappa^{\prime} \alpha\right)$ - Plato argues that the former requires only restitution, whereas injustice calls for punishment, conceived as a measure to improve the soul, affected by disordered emotions or ignorance, causes of injustice.

Keywords: Plato, Laws, Punishment, Greek Law. 


\section{o’rchaí}

no 23, May-Aug. 2018

Silvia Regina da Silva Barros da Cunha, 'Plato's theory of punishment in book ix of Laws', p. 45-75
Greek law generally tended to disregard the mental element of action, its intentionality or lack thereof, but this was certainly not the case in the homicide law. It seems that since an early age the Greeks distinguished between intentional and unintentional homicides, treating the former as worse. In Athens, since the seventh century BC, the homicide law of Draco $^{1}$ explicitly mentioned that in case of unintentional homicide, the murderer should go into exile and stated provisions about justified killings, such as self-defense (Gagarin, 2008, p. 93-99). During the Classical period, the distinction between

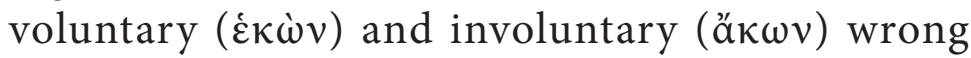
was a central concept, which defines, for instance, if a killing should be considered justified or not and the court responsible for the trial. In fact, the Greek words $\dot{\varepsilon} \kappa \grave{\omega} \nu$ and äk $\omega \nu$, and their correlatives

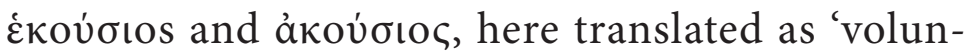
tary' and 'involuntary', have a broader sense and can also mean 'intentional' and 'unintentional', 'willing' and 'unwilling', or 'with consent' and 'forcefully'. Besides the words $\dot{\varepsilon} \kappa \grave{\omega} v$ and "ak $\kappa \omega \nu$, the Greeks use other words to specify the presence or absence of

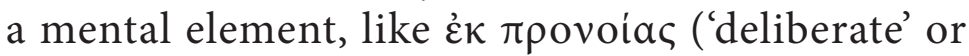
'with premeditation') and à $\pi \rho \circ \beta$ ov $\lambda i \alpha$ ('without planning') and $\mu \varepsilon \tau$ ' $\varepsilon \pi \_\beta o v \lambda \tilde{\eta} \varsigma$ ('with planning'). Although, there was not a clear legal distinction between these terms, which could be subsumed under two broad categories.

In regard to the legal discipline of homicide in Athens at this time, the most important historical sources rely in Antiphon's speeches and a few more by Demosthenes and Lysias. According to these evidences, were considered involuntary, and so lawful, 
cases such as accidental killings of a compatriot in athletic contest; in war or military training or of a patient by a doctor, as result of treatment. It seems that were also considered lawful: the killing of a nocturnal thief who enters the killer's house; a man who kills an adulterer caught in bed with his wife. Concerning procedure, in general terms it could be said that the Areopagus was in charge of trials of voluntary killings of Athenian citizens, when the murderer acts with his own hands. Other cases were assigned to the ephetai, such as: unintentional homicide; charges against a person accused of planning a murder performed by someone else; killings of slaves or strangers (MacDowell, 1978; Todd, 2005; Yunis, 2005; Cohen, 2005b; Gagarin, 2008; 2011).

In Laws, the Athenian Stranger - Plato's voice in which is considered his last work - and his companions, the Cretan Kleinias and the Spartan Megillus, discuss the laws and political institutions they should decree to Magnesia, a new colony to be found in Crete. When the three elders begin to deal with the criminal law, a problem arises. Throughout the dialogue, Plato reaffirmed the thesis according

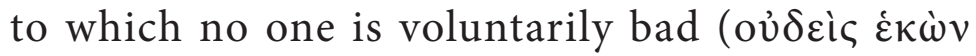
какó $).{ }^{2}$ First the Athenian mentioned that "every unjust man is unjust involuntarily"3 (V 731c2-3: $\pi \tilde{a} \varsigma$

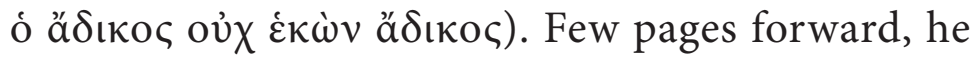
returned to the same point, now saying that "no man can possibly be licentious voluntarily" (V 734b4: $\pi \tilde{a} \varsigma$

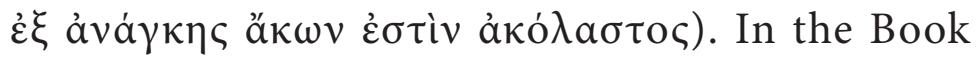
IX, once more he states that "all bad men are in all

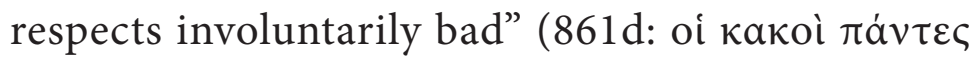

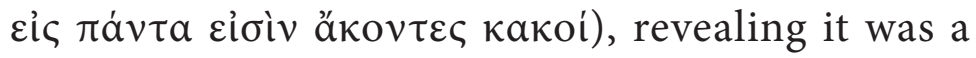
central point in his conceptions about action, which

\section{o’rchaí}

$n^{\circ}$ 23, May-Aug. 2018

Silvia Regina da Silva Barros da Cunha, 'Plato's theory of punishment in book ix of Laws', p. 45-75 


\section{o’rchaí}

no 23, May-Aug. 2018
Silvia Regina da Silva Barros da Cunha, 'Plato's theory of punishment in book ix of Laws', p. 45-75 the lawgiver has to consider in his task of enacting criminal laws.

Confronted with the practical necessity to gradate the penalties, the Athenian acknowledges that this thesis - or rather, his conception about human action - raises a serious problem concerning the institution of criminal law. As he remarks, in all cities, all legislators then known recognized the existence of two forms of offences, the voluntary and

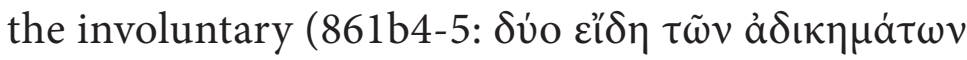

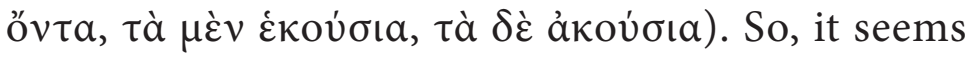
that in his role of legislator he could not adopt this distinction, lest he contradicts himself: having asserted that all offences are involuntary, how could he establish a criminal law that would suit penalties according to the agent's intention or the lack thereof? To overcome this problem, the Athenian must present to his companions a complete punishment theory, in order to justify the imposition of penalties to the criminal, conciliating his thesis

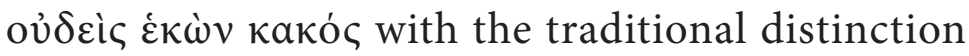
between voluntary and involuntary offences, which he admits he must adopt in his penal code. This is the key issue in Book IX of Laws, where Plato states the basis of legal responsibility in his late thought. ${ }^{4}$

Cleinias introduces the problem. He points out the fact that the same criminal offence (e.g. theft) presents variations that determine its greater or lesser gravity, thus calling for dissimilar penalties. As he says:

How comes it, Stranger, that we are ruling that it makes no difference to the thief whether the thing he steals be 
great or small, and whether the place it is stolen from be holy or unhallowed, or whatever other differences may exist in a theft; whereas the lawgiver ought to suit the punishment to the crime by inflicting dissimilar penalties in these varying cases? (Lg. 857b).

The Athenian does not reply directly to Cleinias' remark; instead, after a long digression, he points to an apparent paradox relating to justice. As he says, when a just punishment is imposed, it is justly endured. However, since the penalty is shameful, it becomes ugly, and consequently devoid of beauty. Seeing that the punishment is just, its endurance should also be considered beautiful, since what is just should not be considered shameful. In this passage (859c-860c), the Athenian points out that the same object, man or action may have distinct predicates, which would sound contradictory to the majority of men.

This topic seems to be left aside by the Athenian. Actually, it will be resumed later, and Plato's purpose here is to introduce the kind of difficulty with which the Athenian will be faced when approaching the core of Book IX. This preamble, crucial to a suitable understanding of the following pages, provides the key to grasp the kind of solution the Athenian has in mind to solve Cleinias' objection.

Plato is clearly aware of the originality of his punishment theory and the difficulties it entails. In the following pages ( $860 \mathrm{~d}-864 \mathrm{c})$ the Athenian scrutinizes his thesis, dwelling upon his arguments, in order to make them clear to his companions. These pages are considered obscure,

\section{ỏrchaí}

no 23, May-Aug. 2018

Silvia Regina da Silva Barros da Cunha, 'Plato's theory of punishment in book ix of Laws', p. 45-75 


\section{o’rchaí}

no 23, May-Aug. 2018

Silvia Regina da Silva Barros da Cunha, 'Plato's theory of punishment in book ix of Laws', p. 45-75 their interpretation being highly controversial, possibly reflecting few corruptions in the Greek manuscripts. For this reason, below they will be examined in five steps.

1 - 860C7-860E47 - THE MAJOR PRINCIPLE REGARDING ACTION AND THE PROBLEM IT POSES TO THE LAWGIVER:

In order to face Cleinias's remark - the inconvenience of imposing an equal penalty without regard to the possible variants of a same criminal offence - the Athenian, recalling his earlier statements, asserts that "all bad men (кakoi) are in all respects

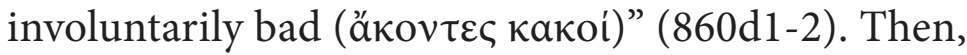
he narrowly draws the consequences from this statement. First, he says, "the unjust man (äßıкó) is, indeed, bad (какóৎ), but the bad man is involuntar-

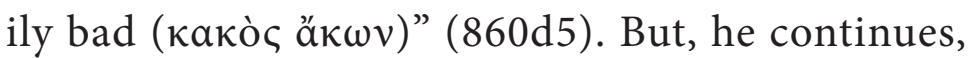
"it is illogical to think that a voluntary act is done

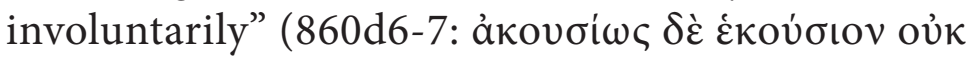

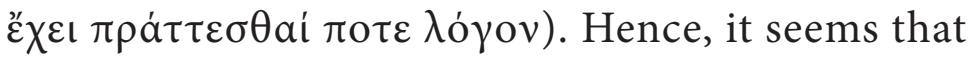
acts involuntarily who commits an injustice, in the eyes of those who assume that injustice is involuntary, a conclusion the Athenian is forced to accept for the sake of his argument's coherence, since he agrees that "all men act unjustly involuntarily"

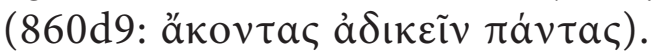

In the following lines (860d9-860e4), the Athenian, in order to clarify his opinion, stresses his disagreement with those who maintain that although men are involuntarily unjust, many commit voluntary acts of injustice. ${ }^{5}$ Presumably in this passage Plato had a particular opinion in view, most likely Aris- 
totle (cf. Robin, 1950, p. 966, n.2; England, 1921, p. 393). In any case, the Athenian's effort to elucidate his thesis, rejecting doctrines that might be similar to his, is worthy of note, and must be taken into account when interpreting the passage.

In conclusion, it seems that Plato's aims in this section are basically two: first, to shed light on his claim that all offences are involuntary, distinguishing it from others similar thesis; and second, to put forward the puzzle his thesis creates for the lawgiver, that could not dismiss the distinction between voluntary and involuntary offences.

\section{2 - 860e8-861D9 - The ACKNOWLEDgement OF} THE EXISTENCE OF TWO CLASSES OF OFFENCES AND THE RESUMPTION OF THE PARADOX CONCERNING JUSTICE:

Faced with the puzzle his thesis seems to have brought him, the Athenian asks his companions if they will make a distinction between voluntary

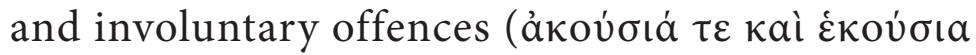

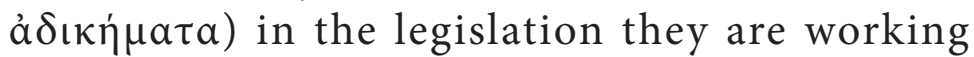
on, assigning heavier punishments to voluntary

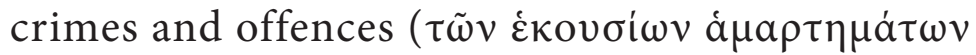

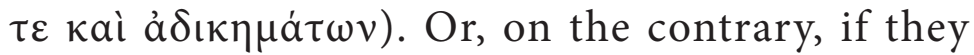
should assign a single punishment to all of them, on the basis that there are no voluntary offences (860e8-861a2).

In view of his assertion that every injustice is involuntary, the Athenian could have simply chosen to assign the same punishment to every type of criminal offence. Nonetheless, he dismisses

\section{o’rchaí}

nº 23, May-Aug. 2018

Silvia Regina da Silva Barros da Cunha, 'Plato's theory of punishment in book ix of Laws', p. 45-75 


\section{o’rchaí}

no 23, May-Aug. 2018

Silvia Regina da Silva Barros da Cunha, 'Plato's theory of punishment in book ix of Laws', p. 45-75 this solution, acknowledging that there are in fact "two kinds of offences, voluntary and involuntary"

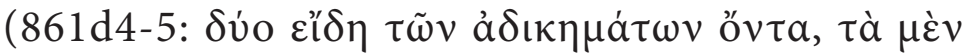

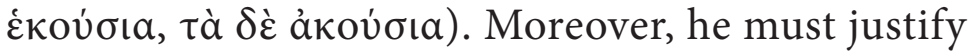
how these different degrees of punishment are to be applied, so that anyone may be able to appraise and judge the rightfulness of the punishment imposed. Therefore, and since, in his view, the traditional classification does not seem to be compatible with his major principle concerning human action, the Athenian must elucidate "how such acts are twofold, if the difference does not lie in that between

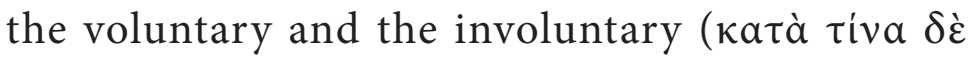

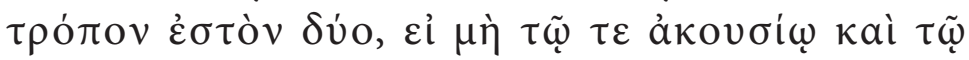

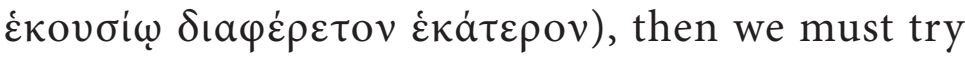
to explain it by means of some other distinction" (861d5-7).

At this point, the Athenian recalls the paradox concerning justice, referred above, and which had not been solved. Establishing a parallel with the situation he must face - explaining the difference between two types of offences -, the Athenian suggests that both are similar issues. Just as, in regard to punishment, to the masses there seems to be a clear separation between the just and the beautiful - which is solely apparent - they must examine whether there is any contradiction in the Athenian's punishment theory, to whom wrongdoings are always involuntary, but who, at the same time, acknowledges the existence of two classes of offences, commonly referred to as "voluntary" and "involuntary". Maybe this incongruence is illusory rather than real, existing only in the eyes of the masses. 
3 - 861E1-863A - THE DISTINCTION BETWEEN INJURY ( $\beta \lambda \dot{\alpha} \beta \eta)$ AND INJUSTICE (ådıkía):

The first step in the Athenian's solution to the difficulty he faces lies in the distinction he estab-

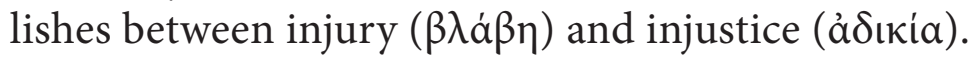
He begins by introducing a new concept, the injury. As he says, "in dealings and intercourse between citizens, injuries committed by one against another are of frequent occurrence, and they involve plenty of the voluntary as well as of the involuntary" (861e1-3). Then, he warns his companions not to think of all injuries as acts of injustice and then regard the unjust acts involved as two-fold as if some were voluntary and others involuntary (861e6$862 \mathrm{a} 2$ ). Indeed, he rejects the idea that "when a man harms ( $\pi \eta \mu a i v \varepsilon l)$ another without wishing it

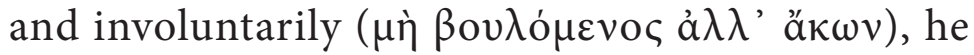

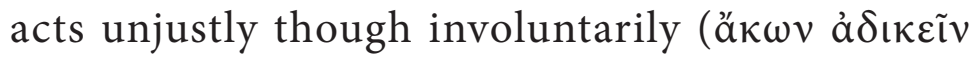

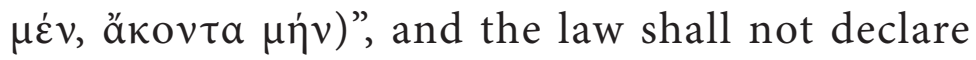

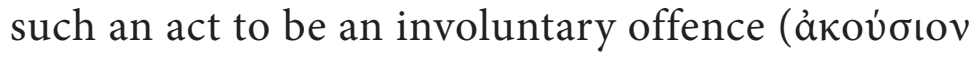
ả $\delta \dot{\kappa} \eta \mu \alpha)(862 \mathrm{a} 3-5)$.

The Athenian rejects here the widely held view that all injuries are acts of injustice, and that these, in turn, could fall into two categories, voluntary and involuntary. The thesis rejected by the Athenian could be presented in the following diagram:

INJURY = INJUSTICE

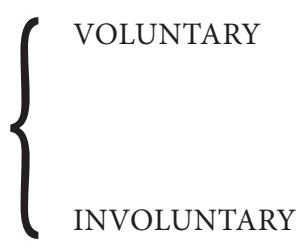

\section{o’rchaí}

no 23, May-Aug. 2018

Silvia Regina da Silva Barros da Cunha, 'Plato's theory of punishment in book ix of Laws', p. 45-75 


\section{o’rchaí}

no 23, May-Aug. 2018
Silvia Regina da Silva Barros da Cunha, 'Plato's theory of punishment in book ix of Laws', p. 45-75
Instead of this misconception, the Athenian asserts:

I will pronounce that such an injury is not an injustice at all, whether it be a greater or a smaller one. And, if my view prevails, we shall often say that the author of

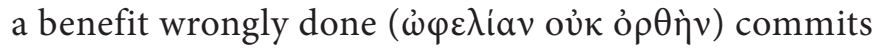
an injustice. In effect, my friends, neither when a man gives things (öv $v \omega v)$ to another, nor when, inversely, he takes them away, one should not proclaim, without further inquiry, such an act just or unjust; but only if a person benefits or causes injury to another with just character $(\tilde{\eta} \theta 0 \varsigma)$ and attitude ( the lawgiver must look at. (862a5-b5)

Actually, the lawgiver should consider two phenomena: injustice and injury. With regard to injury, he should seek to compensate it by all legal means, redeeming what was lost, restoring what was damaged, remedying death and wounds, so as to turn the offender and the victim of each case of injury from a situation of discord to a condition of friendship (862b5-c4). On the other hand, in respect of unjust

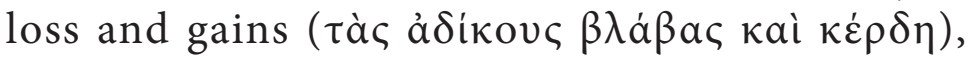
when one commits an unjust act which results in a gain for someone else, every reparable case should be repaired, considering injustice a disease of the soul, that calls for cure (862c6-9).

The remedy the Athenian proposes for injustice, a pathological state of the soul, combines instruction and constraint. The noblest laws should make men hate injustice or, at least, not hate justice. To achieve this aim, the lawgiver can make use of any means such as actions or speeches, pleasures or pains, honors and dishonors, money-fines or money-gifts. And 
to those who prove to be incurable will be assigned the death penalty which, besides profiting both the criminal and society, serves as a warning, so that others will not feel tempted to commit injustices (862d1-863a2). The Athenian conceives punishment as a tool for healing the criminal's soul, compelling him not to commit any other injustice, or to do so less often. In conclusion, punishment is a therapy for the unjust soul and shall not be confused with the restitution of the losses caused by offences, but occurs in addition to it.

In point of fact, there are two main lines of interpretation of this passage. According to the first one, in the general kind "injury" $(\beta \lambda \alpha \dot{\alpha} \beta)$, Plato would have distinguished two different types: the involuntary and the voluntary, the latter being the only one to constitute injustice (Adkins, 1960, p. 305-306; Mackenzie, 1981, p. 200-204; Roberts, 1987, p. 398; Saunders, 1968, p. 423). The second interpretation is that the legislator shall consider two distinct aspects of the criminal offence: injury and injustice. On the one hand, injury, a phenomenon that is purely external and objective, which are losses or gains occurring in the context of mutual relationships between citizens. When a damage occurs, the legislator must make sure it will be repaired, restitution that shall be imposed regardless of the agent's intention or state of soul. The legislator's goal here is to assure social harmony. Besides injury, there is injustice, a subjective phenomenon that refers to the state of the agent's soul, which may cause injury or benefit. Injustice must be corrected through punishment, the purpose of which is reestablishing the soul's health. The fact that injustice causes not only

\section{a’rchaí}

$n^{\circ} 23$, May-Aug. 2018

Silvia Regina da Silva Barros da Cunha, 'Plato's theory of punishment in book ix of Laws', p. 45-75 


\section{o’rchaí}

no 23, May-Aug. 2018

Silvia Regina da Silva Barros da Cunha, 'Plato's theory of punishment in book ix of Laws', p. 45-75

damages, but also benefits - as stated twice by the Athenian (862a7-8; 862c6) - seems to lead to the conclusion that injury and injustice fall into two separate categories. Furthermore, when detailing the criminal legislation, Plato never employs the expressions "voluntary injury" and "involuntary injury", which suggests that the second interpretation is more accurate.

Graphically, the two possible interpretations of the Athenian's posited thesis in this passage can be represented as follows:

INTERPRETATION 1

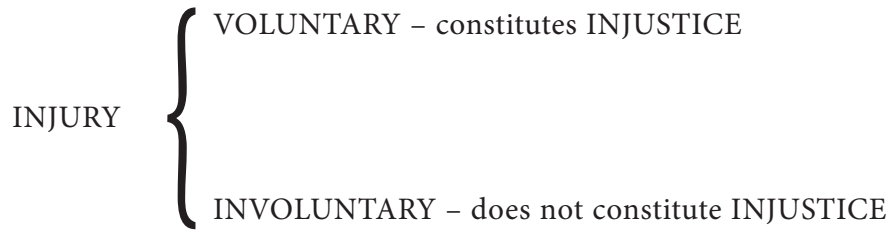

INTERPRETATION 2

ASPECTS OF THE OFFENCE $\left\{\begin{array}{l}\text { INJURY (objective category) - } \\ \text { requires restitution } \\ \text { INJUSTICE (subjective category) - } \\ \text { requires punishment }\end{array}\right.$

In any case, the distinction conceived by the Athenian between injury and injustice seems to have not elucidated the double aspect of offences and the difference between them. In truth, in the lines under 
review, the Athenian's intention is to make it clear that what determines the justice or injustice of an act is not the loss or gain that may come from it, but the character or disposition of the agent. Therefore, to those who understand that an injury may be voluntary or involuntary (Interpretation 1 above), it appears that somehow the only thing Plato did was to shift the difficulty, without effectively solving the problem. It is as if, by means of a simple word play, that which had traditionally been seen as "involuntary injustice" would come to be considered "involuntary injury". Nonetheless, the reason why an action deemed involuntary can also be considered voluntary remains to be explained. On the other hand, for those who understand that injury and injustice are independent categories (Interpretation 2), the passage in question leads to the conclusion that injury and injustice would represent two aspects of wrongdoings. This, however, is still not satisfactory, since it does nothing to clarify the issue pertaining to varying degrees of punishment. Therefore, a second step is necessary to solve the challenge the Athenian faces.

\section{4 - 863 A3-863E 3 - The CAUSES OF MAN'S FAUltS} AND THE VARIOUS ASPECTS OF THE VOLUNTARY AND THE INVOLUNTARY:

Cleinias asks the Athenian for "a clearer explanation respecting the difference between injustice and injury, and that between voluntary and involuntary acts, how these are blended of various forms"

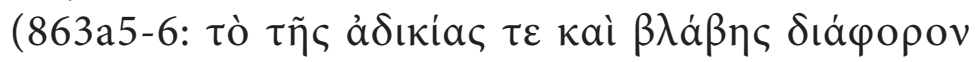

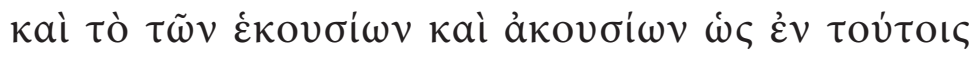
$\left.\delta \iota \alpha \pi \varepsilon \pi \circ i_{k \iota} \lambda \tau \alpha \iota\right)$. Instead of a direct answer, the

\section{o’rchaí}

no 23, May-Aug. 2018

Silvia Regina da Silva Barros da Cunha, 'Plato's theory of punishment in book ix of Laws', p. 45-75 


\section{o’rchaí}

no 23, May-Aug. 2018
Silvia Regina da Silva Barros da Cunha, 'Plato's theory of punishment in book ix of Laws', p. 45-75
Athenian makes a detailed account of causes that lead men to commit faults.

Anger $(\theta v \mu$ ó $)$, the first one - be it a part ( $\mu \dot{\varepsilon} \rho \circ \varsigma)$ or a state $(\pi \dot{\alpha} \theta 0 \varsigma)$ of the soul - is an innate possession, contentious and hard to fight against, that convulses many things by its irrational force. The second cause, pleasure ( $\dot{\eta} \delta o v \eta \dot{)}$ ), exerts its dominance through persuasion and compelling deceit. The

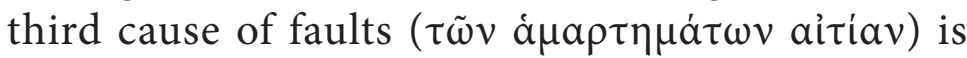
ignorance (ä $\gamma$ vola), which can be divided into two categories: simple ignorance, which leads to lesser faults; or double ignorance, which is coupled with the illusion of wisdom. Coupled with weakness double ignorance leads to childish or senile faults; joined with strength and vigor, however, it can cause graver, more brutal faults.

This passage could be represented by the following diagram:

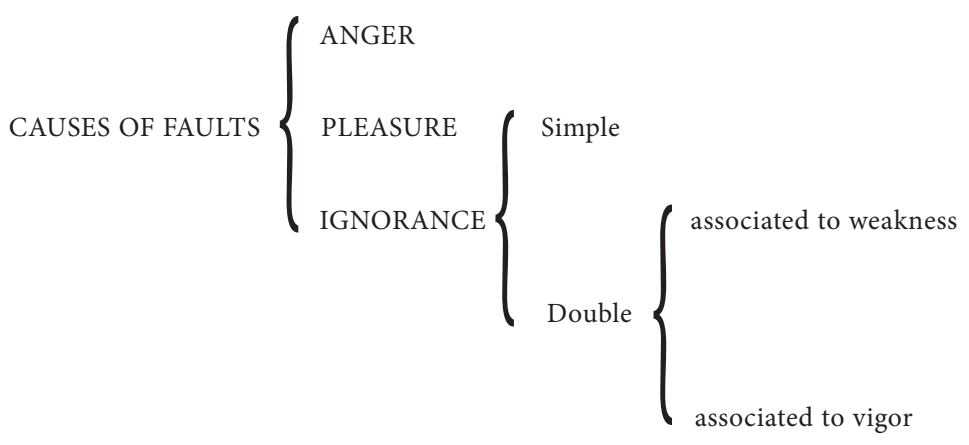

As almost everyone says - adds the Athenian between men, one masters anger and pleasure and another is mastered by them. However, nobody says that a man masters and another is mastered 
by ignorance ( $863 \mathrm{~d} 6-\mathrm{e} 1)$. Still, these states of soul anger, pleasure - as well as ignorance, "we say that all of them urge each man on a direction counter to his own will and for which he is attracted to"

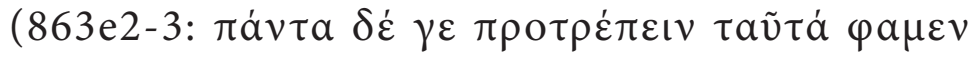

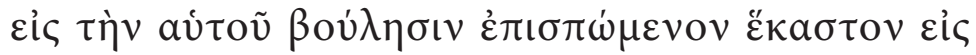

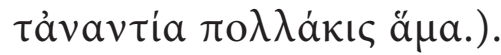

The sentence at $863 \mathrm{e} 2-3$ reveals the sense in which we should understand the Athenian's statement that no one is bad voluntarily. States of soul, such as anger or pleasure, as well as ignorance are the factors that cause wrongdoings, which are involuntary because these forces act on the human soul compelling men in a way that is contrary to their own bent, their on will.

A corresponding idea can be found in the Sophist (227d-229c), when the Visitor from Elea divides the vices (какiac, 227d) of the soul into two categories. Just like the body may have two types of flaws,

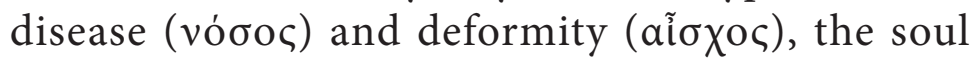
also presents two distinctive kinds of vice. The first,

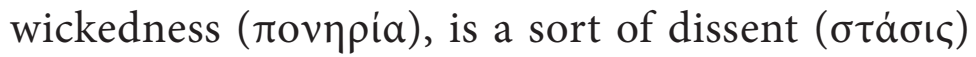
in the soul and resembles a disease, being characterized by the conflict between opinions and desires, or between courage and pleasure, or yet between reason and pain. The second, ignorance (å $\gamma v o r \alpha)$, is a kind of deformity, a disproportion (å $\mu \varepsilon \tau \rho i \alpha)$ of the soul (228d). Like a physical deformity, it is a derangement

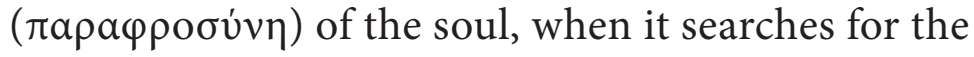
truth, but is unable to find it. In its turn, ignorance may be divided into two species, being the more serious called stupidity (å $\mu \alpha \theta i \alpha)$, the condition in which man presumes to know what in fact he ignores.

\section{o’rchoí}

no 23, May-Aug. 2018

Silvia Regina da Silva Barros da Cunha, 'Plato's theory of punishment in book ix of Laws', p. 45-75 


\section{o’rchaí}

no 23, May-Aug. 2018

Silvia Regina da Silva Barros da Cunha, 'Plato's theory of punishment in book ix of Laws', p. 45-75
In comparison to Republic, these passages from Laws and Sophist reveal an evolution of Plato's thought respecting the human psychology. In $R e$ public, the injustice of the soul was regarded as a disharmony between its appetitive, impetuous and rational elements. In that context, well-founded knowledge would represent effective means of acquiring virtue and, as long as the rational element was kept in charge of the others, the soul would become just. As his ideas evolved, Plato discerned a nuance that leads him to distinguish the internal conflict between reason and emotions from the pure and simple intellectual flaw, both causes of wrongdoings. In the first case, Plato acknowledges that occasionally emotions may be controlled or persuaded by reason. But even when this does not happen, and man is led to misbehave due to the dominance that anger, fear and pleasures exert over his soul, his reason is not entirely obscured: its voice can still be heard, and man, in greater or lesser degree, is conscious of having misbehaved, although he might be unable to resist the impulse of his emotions. On the other hand, because of its direct effect over the rational element of the soul, ignorance, in a way, is a more insidious cause of wrongdoings. Moved by ignorance, the reason's voice will be unable to argue against error, and the man can not realize his fault.

If in the Sophist Plato was concerned with a classification of the causes of vice, the purpose of this passage of Laws is to expose the multiple meanings of voluntary and involuntary. Considering that the ultimate goal of human actions is a life in which, in its final reckoning, pleasure supersedes pain, it is possible to say that all wrongdoings are involuntary, 
seeing that they result from states of the soul that compel man to act in a manner that is contrary to his final will and real purpose. Even in this sense, the Athenian proved that the involuntary has different hues, depending on whether the mistake results from ignorance or affections. In the first case, the wrongdoing is said to be involuntary because the individual's reason is obscured by ignorance. In the second hypothesis, the involuntary refers to the moral impotence of reason in face of the compulsion of affections. The different meanings or degrees of voluntary and involuntary will prove crucial for enacting penalties.

On the other hand, it is possible to think about the intention and the will as referred to the immediate objective of an action. Then, it is possible to say that a particular act - a murder, for instance - is voluntary, meaning that it was deliberately committed, in contraposition to accidental or compulsory actions. So, according to the angle from which the agent's will and intention are analyzed, the same action could be predicated in two different ways. In the strict sense of voluntary, which denotes the immediate objective of the action, it would be right to say that a man acts voluntarily, provided that he was not compelled to act, and the result of his action did not take place by mere accident or against his immediate will. At the same time, regarding the final purpose of human life, one can say that a man acts involuntarily if his actions results in more pain than pleasure or happiness.

Now it is possible to understand the function of the passage $859 c-860 c$, where the Athenian mentions a kind of linguistic confusion, which seems to the

\section{o’rchaí}

no 23, May-Aug. 2018

Silvia Regina da Silva Barros da Cunha, 'Plato's theory of punishment in book ix of Laws', p. 45-75 


\section{o’rchaí}

no 23, May-Aug. 2018

Silvia Regina da Silva Barros da Cunha, 'Plato's theory of punishment in book ix of Laws', p. 45-75 multitude to be a paradox concerning justice. In fact, there is no contradiction in considering a certain criminal offence to be voluntary, meaning that the action was deliberately perpetrated by its author, while at the same time maintaining the thesis that no one does evil voluntarily. With this demonstration that the terms voluntary and involuntary have various meanings, the Athenian leads his companions to conclude that there is no linguistic incoherence nor any logical conflict in the proposition upon which he bases his punishment theory, and the fact that, as a legislator, he adopts the traditional terms

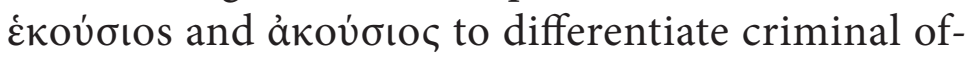
fences that are intentionally committed from those that are unintentional or accidental.

\section{5 - 863E5-864C10 - A NEW EXPLANATION OF THE} DIFFERENCE BETWEEN INJUSTICE AND INJURY:

As seen (Section 4 above), Cleinias had asked clarification of two points: the difference between injury and injustice; and the various senses of the terms voluntary and involuntary. Having examined the latter one, the Athenian now must attend to the former. He begins by defining what he understands by justice and injustice: "the tyranny of anger, fear, pleasure, pain, envy and desires in the soul, whether or not this results in injury, I term generally injustice" (863e6-864a1). The following sentence says:

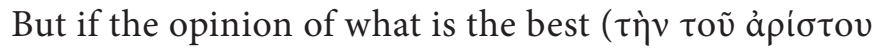
$\delta$ ó $\xi \alpha v$ ), by whatever way a city or private citizens think they can attain to it - if this has supreme authority over their souls and regulates $(\delta\llcorner\alpha \kappa o \sigma \mu \eta \tilde{\eta})$ every man,

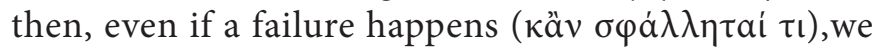


must say that is just everything done this way and whatever in each man is obedient to this governance is to be called just and best for the whole of human life, though most men suppose that such injury is an involuntary injustice. (864a1-8)

After this difficult passage the Athenian mentions once again the three forms of faults (864b1:

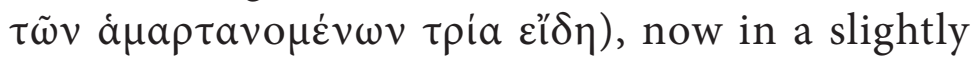
different way. The first one involves pain $(\lambda \dot{\pi} \pi)$,

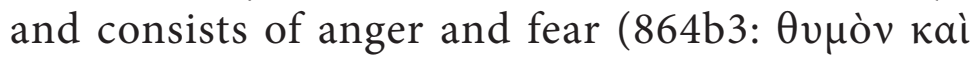
$\varphi$ ó $\beta$ ov). The second, of pleasures and appetites

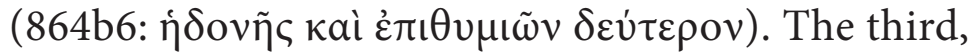
according to the Athenian, belongs to a distinct kind

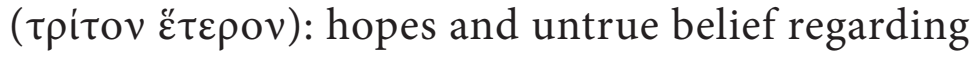
the attainment of the highest good (864b6-7: $\dot{\varepsilon} \lambda \pi i \delta \omega v$

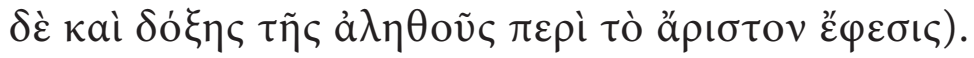
And here some authors suggest a corruption of the Greek manuscripts: in place of $\varepsilon_{\varphi} \varphi \sigma \iota \varsigma$ (impulse) of the manuscripts, they think that the correct term would be ä $\varphi \varepsilon \sigma ı \varsigma$ (loss). Whatever the case might be, there seems to be consensus that the third cause of faults the Athenian refers to is ignorance.

Recalling that ignorance, in turn, can be divided into three classes (cf. Section 4), the Athenian concludes that there are five classes of faults, to which different laws should apply, of two main types - acts of violence that are openly perpetrated, and veiled acts that involve fraud -, so closing the explanation promised to Cleinias. Thereby, he gets back to the point that originated the digression, when deliberating on the issue of theft, he would have imposed a single punishment, that is, the restitution of twice the value of the stolen object. Now, considering the

\section{o’rchaí}

no 23, May-Aug. 2018

Silvia Regina da Silva Barros da Cunha, 'Plato's theory of punishment in book ix of Laws', p. 45-75 


\section{o’rchaí}

no 23, May-Aug. 2018

Silvia Regina da Silva Barros da Cunha, 'Plato's theory of punishment in book ix of Laws', p. 45-75 possibility that such crimes might be committed by people who are under a state of insanity, such as senility, madness, or infantile behavior, a lesser punishment is prescribed for these cases: the restitution of the value of the stolen object. In the subsequent passages in Book IX, the Athenian will classify the different kinds of homicides into four categories, which will be examined below.

Even though the meaning of the sentence in 864a1-8 is controversial and, as mentioned, a corruption of the Greek manuscripts should not be ruled out, the key expressions to understand the passage

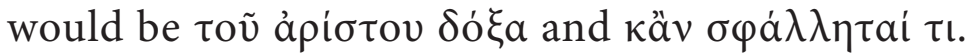
According to the commonly accepted interpretation of these lines, justice consists in the observation of a pattern that is merely internal, the voice of conscience. Out of the three causes of faults mentioned by the Athenian, the two first ones, $\theta v \mu$ ó and $\dot{\eta} \delta o v \eta \dot{n}$, would characterize injustice in the soul. On the other hand, faults caused by ä $\gamma v$ o

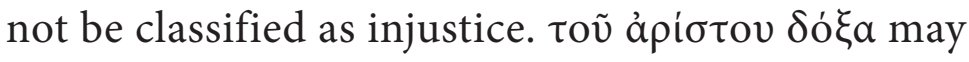
refer to a true view as well as an equivocal view, or

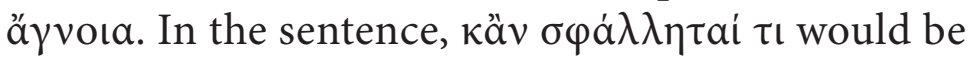

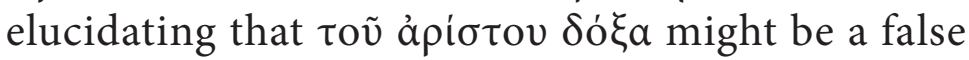
view. Thus, if injustice consists in observing one's own judgment regarding right and wrong, this would be equivalent to obeying the voice of conscience. ${ }^{6}$

This interpretation seems to conflict with lines 863c1-d4, where the Athenian associates ignorance with more serious and brutal wrongs, and would represent a radical change in Plato's thought. It also sounds incompatible with the passage from Book X in which Plato reserves the death penalty to the impi- 
ous, in spite of acknowledging that some might love justice and be thus sincerely wrong in their beliefs. If the traditional interpretation is correct, the impious who would be acting according to the voice of his conscience, would not have committed any injustice, and thus would not be deserving of any punishment.

In a thorough analysis, O’Brien (1957, p. 84-87) has proposed a new interpretation of the passage. Anger, pleasure and ignorance are expressions of injustice since, either directly through violence, or indirectly through the submission of the intellect, these three causes of faults compel man to act in a manner contrary to his own wellbeing. Therefore, the definition of justice in 864 a 1-8 could not include the

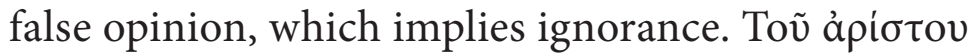
$\delta$ ó $\xi$ a must be understood as "the conviction which has the best for its object" instead of "the opinion as

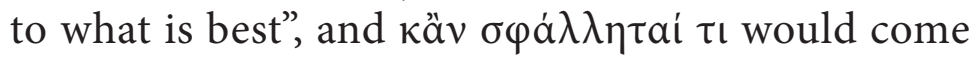
to mean "even if there is a slipup," rather than "even if some injury be done".

A third line of interpretation would be of Görgemanns (1960, apud Saunders, 1968, p. 429-430) to

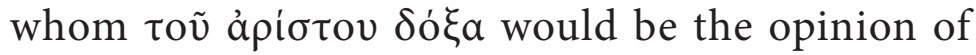
the means by which the best may be achieved, since,

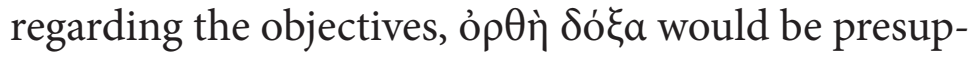

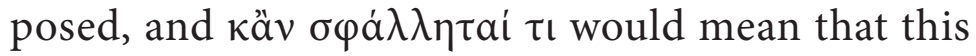
opinion of the means might be wrong, leading to errors that should be deemed as just. In its essential aspects, this seems to be Stalley's (1983, p. 157-159)

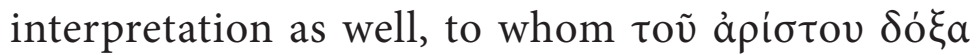
would be "the correct conception of the good", and

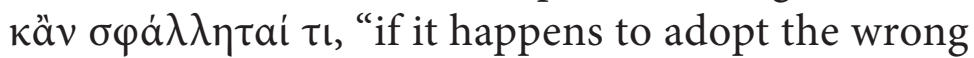
means”. Analyzing Görgemanns' interpretation,

\section{o’rchaí}

no 23, May-Aug. 2018

Silvia Regina da Silva Barros da Cunha, 'Plato's theory of punishment in book ix of Laws', p. 45-75 


\section{o’rchaí}

no 23, May-Aug. 2018
Silvia Regina da Silva Barros da Cunha, 'Plato's theory of punishment in book ix of Laws', p. 45-75
Saunders (1968, p. 429-430) objected that the statement that the $\delta$ ó $\xi \alpha$ must dominate the soul of each man seems to be much better suited to the correct opinion of the ends than to a practical judgment of the means. Moreover, the structure of the argument

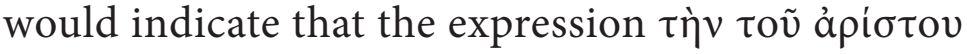
$\delta$ ó $\xi \alpha$ must be understood in an intellectual and theoretical sense, rather than a practical one.

Yet a fourth interpretation is the one proposed by Saunders (1968, p. 430-432; 1991, p. 146-150), whose view is based on the structure found in lines 863a3-864c2. When anger, fear, pleasure, pain, envy, and desire dominate the soul, regardless of whether or not any injury may result, injustice takes place. On the contrary, as long as the correct moral view governs the soul, any action thus effected is just, even if this view is not entirely correct - this being

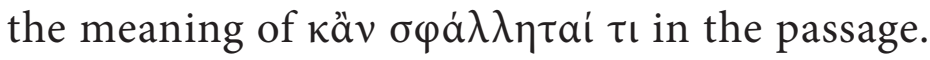

As seen, the sentence in $863 \mathrm{e} 6-864 \mathrm{a} 1$ affords the most varied interpretations. Although O'Brien's study did not remain immune to criticism, ${ }^{7}$ it has provided this difficult passage with an interpretation that is more coherent not only with Laws, but also with the Platonic doctrine as a whole. Actually, the critical point to the understanding of these lines seems to be that when the Athenian

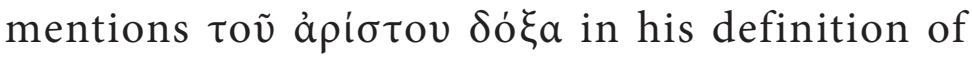
justice at $864 \mathrm{a} 1-8$ he did not intend to assert that acts committed by ignorance could be considered just acts. In fact, that would be totally incongruent with passage in 863b1-e4, where he states that

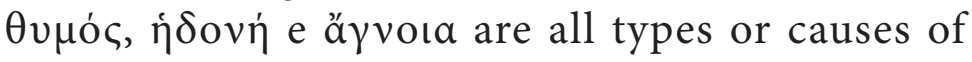
faults, and that they are forces that drag a man 
in a direction contrary to his own wish. This be-

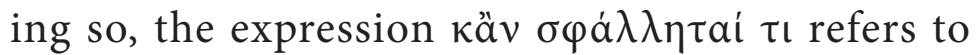

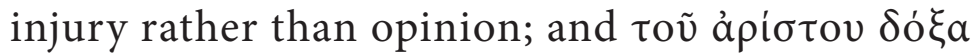
denotes a man's opinion, conviction, or reflection regarding what is best. Having settled what seems to be the most controversial point, it's possible to understand the meaning of the passage as a whole.

In order to comply with Cleinias' request for a clearer explanation of the difference between injustice and injury, the Athenian firstly defines injustice as the tyranny of the emotions over the soul. In addition to anger and pleasure, previously mentioned as causes of man's faults (863b), at this moment the Athenian includes fear, envy, pain, and desire. His point now is to make clear that emotions in general are forces capable of burdening the soul, driving man to act in ways that are contrary to his real intent and will.

Apparently forgetting ignorance, previously mentioned as the third cause of man's faults (863c1-2), the Athenian presents his concept of justice: the supreme authority of the opinion of what is best over the souls, guiding the city and individuals. Everything that is done in this spirit shall be considered just, even if some injury is produced - and even if the multitudes should regard this as involuntary injustice. Actually, justice in the soul does not entail that injury will not occur and the men who have just souls are not exempt from suffering or causing injury. Seeing that there is no disease in this man's soul, the legislator's duty is simply to make sure that such injuries are repaired.

Contrasting injustice - a phenomenon of the soul - and injury - a merely external fact - the Athenian

\section{o’rchaí}

nº 23, May-Aug. 2018

Silvia Regina da Silva Barros da Cunha, 'Plato's theory of punishment in book ix of Laws', p. 45-75 


\section{o’rchaí}

no 23, May-Aug. 2018

Silvia Regina da Silva Barros da Cunha, 'Plato's theory of punishment in book ix of Laws', p. 45-75 clarifies his notions, repeating that his doctrine diverges from that of the common man, to whom the injury incurred by the just man would amount to an act of involuntary injustice. And why the Athenian did not mention ignorance in this passage? It's possible to think that Plato's aim here is to draw the attention to the yoke of the emotions over reason, governing the soul and directing human actions. This is precisely what constitutes injustice. Ignorance, on the other hand, the intellectual flaw that originates false beliefs, is the factor that allows emotions to guide the soul in place of those principles which, by nature, should reign over it: knowledge, opinion, and reason.

The focus of Laws is eminently practical: Plato is interested in the common man and how to conduct individuals and the city to a virtuous life. As the Athenian says, only a privileged few manage to consolidate prudence and true opinions, and they should consider themselves lucky who acquire these even in their old age (II, 653a). Therefore, realistically speaking, in 864a Plato defines justice in terms of opinion, which, more than wisdom, is what we can expect to ultimately steer individuals as well as the city.

With the essential difference between injustice and injury having been duly settled, and in order to dissipate any doubts, the Athenian goes back to the classification of the causes of faults, which fall under the three categories afore mentioned: 1 - painful factors, consisting of anger and fear; 2 - persuasive ones, which include pleasures and appetites; 3 - ignorance, which can be subdivided into three classes. Evidently, the purpose of this repetition is to leave 
no doubts that if injustice is a kind of disharmony or disorganization of emotions, be it painful or not, the lawgiver should consider that there are three factors that lead men to commit faults.

Once the theoretical bases of punishment were established, the Athenian can detail the legal discipline applicable to homicide, imposing lighter or heavier penalties according to the severity of the offense, corresponding to the criminal intention, which results in the following categories. The first one consists of violent and involuntary homicides, by means of a direct action by the murderer, such as deaths in military training, public games or as result of a medical treatment (865a1-866d5). The second category covers the homicides in anger $(\theta v \mu o ́ \varsigma)$, classified as intermediate between the voluntary and the involuntary, and which include two types: without previous intent; and by revenge, with premeditation (866d6-869e5). The third kind are voluntary and premeditated homicides, motivated by pleasure, appetites, and envy (869e6-873c1). And the last one consists of killings exempted of punishment (874b6-d1).

An extensive analysis of these dispositions is not the focus of this work. In a general approach, it may be noted that the Attic homicide law, both substantive and procedural, is Plato's major reference. In fact, in many relevant aspects, Plato upholds in his penal code the main features of Attic law, such as: 1 - the relatives were responsible for the persecution of the killer; 2 - the hypotheses of involuntary and violent killings (865a1-866d5) and killings exempted of punishment (874b6-d1) were basically the same

\section{o’rchaí}

no 23, May-Aug. 2018

Silvia Regina da Silva Barros da Cunha, 'Plato's theory of punishment in book ix of Laws', p. 45-75 


\section{o’rchaí}

no 23, May-Aug. 2018

Silvia Regina da Silva Barros da Cunha, 'Plato's theory of punishment in book ix of Laws', p. 45-75 portrayed by the forensic speeches as lawful; 3 - the legal distinction between planning and killing with one's own hands; 4 - there were different legal consequences between the killing of an Athenian citizen and the killings of slaves and foreigners. Probably the most striking feature of Plato's penal code is the notion of homicide in anger, an intermediary class between the voluntary and the involuntary killing. If his theory of punishment is or not consistent with the criminal law he establishes for the fictitious colony of Magnesia is a controversial point. ${ }^{8}$

\section{Conclusion}

The solution devised by the Athenian to overcome the puzzle that challenged him - that is, how to con-

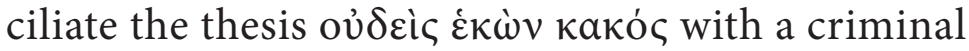
law that settles on a gradation of penalties, on the basis of the traditional distinction of voluntary and involuntary crimes - rests on the demonstration that

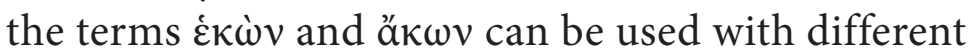
meanings. Strictly speaking, the Athenian's line of reasoning could have dispensed with the distinction between injustice and injury. Therefore, the demonstration that criminal offence has two distinctive aspects, injury and injustice, must have a function other than the first reading of these pages suggests.

Far from being an abstraction, devoid of practical consequences, the passages from Book IX under discussion evince Plato's late ideas about the basis of moral responsibility, under an objective standpoint, that is, the perspective of the legislator who, when enacting criminal laws, must answer the following question: what justifies the imposition of punishment 


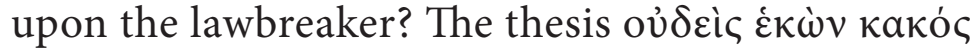
is the basis upon which lies both his punishment theory and the structuring principle of his criminal laws. This thesis is combined with a new conception of crime as being composed of two distinct aspects, injury and injustice, which require different legal measures, as they are not necessarily associated.

In regard to injury, an external and objective phenomenon, considering that the citizens, in their mutual relations, deliberately or not, may cause damage to each other, the legislator must make sure that these damages are repaired, seeking to compensate the injured part, so as to guarantee a peaceful social life in the city. On the other hand, injustice, a subjective phenomenon, is the evidence of a disease that infects the soul of the wicked. Although the criminal's evil deed is ultimately perpetrated against his greater interest and good, against his own soul - the reason why his perverse actions are said involuntary - this does not mean that he should go unpunished. On the contrary, punishment is the therapy administered by the legislator, aimed at healing the injustice of the soul. If the criminal's faults are remediable, he is deserving of compassion above all things (731c-d). Even in the case of irrecoverable criminals, deserving of wrath rather than compassion, and to whom Plato prescribes the death penalty, the punishment is considered to be in the best interest of both the unjust man and the polis (854e; 862e). In this respect, more than retaliatory, the punishment takes on a therapeutic character; its purpose is to heal a pathological state of the soul, thus representing a benefit for the criminal. Punishment still has another purpose, one that may be said to be educational or dissuasive: convincing others, through

\section{ỏrchaí}

$n^{\circ}$ 23, May-Aug. 2018

Silvia Regina da Silva Barros da Cunha, 'Plato's theory of punishment in book ix of Laws', p. 45-75 


\section{o’rchaí}

no 23, May-Aug. 2018
Silvia Regina da Silva Barros da Cunha, 'Plato's theory of punishment in book ix of Laws', p. 45-75 the example set by the penalty justly imposed upon the criminal, that injustice is not advantageous. The punishment theory outlined by the Athenian in Book IX of Laws demonstrates how Plato managed to conciliate the idea - consistently affirmed throughout his work - that evil is involuntary, with the legislator's practical needs, thus providing a rational justification for the punishment.

\section{ENDNOTES}

1 According to the tradition, the first written laws in Athens were enacted by Draco in 621/0 BC. In the early sixth century his code was repealed at the Solon's reform, with the sole exception of the homicide law, which the Athenians believed that remained unaltered during the Classical age.

2 Besides $L g$. this thesis, usually ascribed to Socrates, with slight different formulations, occurs in Prt. 352b ss; Grg. 468c, 509 ss; Men. 77d-e; R. 382a, 413a, 443e ff; Sph. 228c-e; Ti. 86d-e (Apud Robin, 1950, p. 783, n.2).

3 All translations from Greek text by Bury, with minor changes.

4 The problem of the rational justification for the imposition of punishment has been first discussed by Plato in Prt. 324a-c. He was not alone in this matter; during the Classical age, other thinkers also advanced different punishment theories. Cf. Cohen (2005a, p. 170-190).

5 It is a problematic sentence and here I took into account the correction made by Shorey (1926, p. 404-405) to Bury's translation.

$6 \quad$ O'Brien (1957, p. 81-83) lists scholars whose interpretations largely coincide with Ritter's, who, in turn, is regarded as parameter for the traditional interpretation: Stallbaum, Grote, Apelt, Gernet, England, Taylor, Grube, Levinson, Hackforth. In addition to these, we could also include Adkins (1960, p. 308): "If a man's reason and desires are not in conflict, whatever his basic view of life, he is to be termed dikaios, provided that his actions are based on reason, not passion or desire." Roberts (1987) also seems to accept the traditional interpretation. On

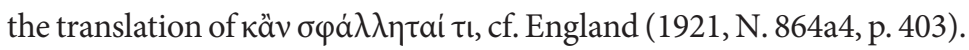

7 Saunders, 1968, p. 429. For a more recent analysis of these passages, cf. Weiss, 2006. According to Trelawny-Cassity, 2010, these two are the best commentaries on Book IX of Laws.

8 Cf. Trelany-Cassity (2010) for a more recent view on this topic. 


\section{BIBLIOGRAPHY}

ADKINS, A.W. H. (1960). Merit and responsibility. Oxford, Clarendon Press.

BRISSON, L.; PRADEAU, J. F. (2006). Platon. Les Lois (traduction, introduction et notes). 2 vol. Paris, GF Flammarion.

BURY, R. G. (1926). Plato. Laws (translation). Vol. IX and X. London, New York, Loeb Classical Library.

COHEN, D. (2005a). Theories of Punishment. In: GAGARIN, M.; COHEN, D. (ed.). The Cambridge Companion to Ancient Greek Law. Cambridge, Cambridge Univ. Press, p. 170-190.

COHEN, D. (2005b). Crime, Punishment and the Rule of Law in Classical Athens. In: GAGARIN, M.; COHEN, D. (ed.) The Cambridge Companion to Ancient Greek Law. Cambridge, Cambridge Univ. Press, p. 211-235.

ENGLAND, E. B. (1921) (ed.). The Laws of Plato. 2 vol. Manchester, The University Press.

GAGARIN, M. (2008). Writing Greek Law. Cambridge, Cambridge Univ. Press.

GAGARIN, M. (2011) (ed.). Speechs from Athenian Law. Austin, Univ. of Texas Press.

GÖRGEMANNS, H. (1960). Beiträge zur Interpretation von Plato's Nomoi. Munchën, Beck.

HACKFORTH, R. (1946). Moral evil and ignorance in Plato's Ethics. Classical Quartely, 40, p. 118-120.

\section{árchoí}

no 23, May-Aug. 2018

Silvia Regina da Silva Barros da Cunha, 'Plato's theory of punishment in book ix of Laws', p. 45-75 


\section{o’rchaí}

no 23, May-Aug. 2018

Silvia Regina da Silva Barros da Cunha, 'Plato's theory of punishment in book ix of Laws', p. 45-75
MACKENZIE, M. M. (1981). Plato on Punishment. Berkeley, Univ. of California Press.

O'BRIEN, M. J. (1957). Plato and the "good conscience", Laws, 863e5-864b7. Transactions of the American Philological Association, 88, p. 81-87.

ROBERTS, J. (1987). Plato on the causes of wrongdoing in the Laws. Ancient Philosophy, 7, p. 23-37. Also in: IRWIN, T. (ed). Classical Philosophy: collected papers. Vol. 3. Plato's Ethics. (1995) New York, London, Garland Publishing Inc., p. 397-411.

ROBIN, L. (1950). Platon. Oeuvres Complètes (traduction et notes). 2 vol. Paris, Gallimard.

SAUNDERS, T. J. (1968). The Socratic paradoxes in Plato's Laws. Hermes, 96 (3), p. 421-434. Also in: IRWIN, T. (ed.) Classical Philosophy: collected papers. Vol. 3. Plato's Ethics. (1995). New York, London, Garland Publishing Inc., p. 383-396.

SAUNDERS, T. J. (1991). Plato's Penal Code: Tradition, Controversy and Reform in Greek Penology. Oxford, Clarendon Press.

SHOREY, P. (1926). Book Review. Classical Phi$\operatorname{lolog} y, 23$, p. 403-405.

STALLEY, R. F. (1983). An Introduction to Plato's Laws. Oxford, Basil Blackwell.

TODD, S. C. (2005). Law and Oratory at Athens. In: GAGARIN, M.; COHEN, D. (ed.) The Cambridge Companion to Ancient Greek Law. Cambridge, Cambridge Univ. Press, p. 97-111. 
TRELAWNY-CASSITY, L. (2010). Ten Tou Aristou Doxan: On the theory and practice of punishment in Plato's Laws. Polis, 27, N. 2, p. 222-239.

WEISS, R. (2006). The Socratic Paradoxes and Its Enemies. Chicago, University of Chicago Press.

YUNIS, H. (2005). The Rhetoric of Law in FourthCentury Athens. In: GAGARIN, M.; COHEN, D. (ed.). The Cambridge Companion to Ancient Greek Law. Cambridge, Cambridge Univ. Press, p. 191-210.

Submitted in November, 2016 and accepted for publication in February, 2017

\section{órchoí}

no 23, May-Aug. 2018

Silvia Regina da Silva Barros da Cunha, 'Plato's theory of punishment in book ix of Laws', p. 45-75 
